\title{
The Zollinger-Ellison syndrome in a child
}

\author{
H. B. C. BURMESTER, R. HALL, AND N. MUNAWER \\ From the Departments of Pathology, Surgery, and Paediatrics, Bradford $(A)$ Group of Hospitals
}

SUMMARY The Zollinger-Ellison syndrome was encountered in a boy aged 11 years who presented with a bulbar duodenal ulcer causing intractable pain and bleeding. The diagnosis was made by finding an overnight fasting gastric secretion of $1,300 \mathrm{ml}$ containing $134 \mathrm{~m}$-equiv/ $\mathrm{HCl}$, and little change of secretion after maximal histamine stimulus. A circumscribed non-beta islet cell pancreatic tumour was excised, with antrectomy. Postoperative acid secretion was normal and the boy was well after being followed up for 15 months. The diagnosis and management are discussed, as the view that total gastrectomy must be performed in all cases of the Zollinger-Ellison syndrome is questioned.

Zollinger and Ellison (1955) were the first to draw attention to the triad of gastric hypersecretion, recurrent or atypical peptic ulceration, and a non-beta-cell tumour of the pancreas.

Gregory, Tracy, French, and Sircus (1960) extracted a substance from a similar pancreatic tumour with properties resembling those of hog gastrin. Later Gregory, Grossman, Tracy, and Bentley (1967) analysed extracts from two ZollingerEllison syndrome pancreatic tumours and found that the gastrin-like active principle showed an almost identical aminoacid pattern to that of human gastrin.

The first child with a tumour giving a gastrinlike active extract was described in an 8-year-old boy by Jackson, Blair, Dawson, Reed, and Watts (1963). Wilson and Ellison (1965) reviewed the surgical progress of seven patients who had their first operations between the ages of 8 and 15 years, adding a further case. In 1966 they were able to review more than 400 cases of the Zollinger-Ellison syndrome from their registry, including nine children aged 15 years or less. Thus the incidence in childhood appears to be about $2 \%$ of all cases.

\section{CASE REPORT}

A boy aged 11 years presented in September 1966 with a nine-month history of intermittent epigastric pain relieved by food. Barium meal examination of the fasting stomach showed distension with residual fluid, thickening of the gastric mucosal folds, a prominent bulbar duodenal ulcer with gross cicatricial deformity, and marked pylorospasm. In addition the proximal jejunum had a spidery appearance. Stools were negative for occult blood. The haemoglobin level was $14 \cdot 3 \mathrm{~g}$ per 100 $\mathrm{ml}(98 \%)$. There was no family history of peptic ulcer or of endocrine disorder.

Five admissions to hospital within the ensuing 12 months were necessary because of acute exacerbations of pain and vomiting, in spite of strict medical treatment with diet, antacids, and sedatives. In September 1967 the barium meal was repeated. It showed an increase of ulcer size with more obvious scarring. Gastric dilatation was marked and residual fluid present. A fractional test meal showed pronounced hyperchlorhydria. Stools were negative for occult blood but the haemoglobin level had fallen to $10.8 \mathrm{~g}$ per $100 \mathrm{ml}(74 \%)$.

The boy had a further relapse in December 1967. He had a small haematemesis and pain became continuous. Although mildly obese, clinical examination was otherwise unremarkable. The haemoglobin level was $9.9 \mathrm{~g}$ per $100 \mathrm{ml}(68 \%)$. Occult blood was now present in the stools. At this stage a surgical opinion was sought. The Zollinger-Ellison syndrome was considered and operation was advised.

At no time had diarrhoea been recorded.

PREOPERATIVE ACID STUDIES The volume of a 12-hour fasting overnight gastric aspiration was $1,312 \mathrm{ml}$, containing $134 \mathrm{~m}$-equiv of free acid. Augmented histamine stimulation (1.8 $\mathrm{mg}$ histamine acid phosphate) did not result in any further acid release (Fig. 1). In each of the acid studies the aspirating tube was screened to confirm its presence within the stomach.

FURTHER TESTS The following investigations performed to exclude the multiple endocrine adenomata syndrome showed: fasting blood sugar $92 \mathrm{mg}$ per $100 \mathrm{ml}$; serum calcium $9.6 \mathrm{mg}$ per $100 \mathrm{ml}$; serum phosphorus $4.4 \mathrm{mg}$ per $100 \mathrm{ml}$; serum alkaline phosphatase $16 \mathrm{KA}$ units per $100 \mathrm{ml}$; plasma 11-hydroxycorticosteroids $30 \mu \mathrm{g}$ per $100 \mathrm{ml}$ (at the upper limit of normal for the laboratory used, and explicable in terms of the patient's stressed condition). 
A radiograph of the skull revealed no abnormality of the pituitary fossa.

OPERATION Laparotomy was performed by Mr F. R. R. Martin on 20 December 1967. Preliminary abdominal palpation under the anaesthetic revealed an epigastric swelling. At operation it was found to be a large, hard, slightly lobulated tumour lying within the upper surface of the neck of the pancreas. The remainder of the pancreas and the liver appeared normal. No other abdominal tumours were detected. There was a postero-inferior chronic duodenal ulcer $3 \mathrm{~cm}$ in diameter adherent to the pancreas adjacent to the tumour, and it had given rise to a trefoil duodenal deformity with early pyloric stenosis. Local resection of the tumour was carried out easily without entering the pancreatic duct system. The duodenum was separated from the ulcer, which was left in situ and its base coagulated using diathermy. After closing the duodenum, a one-third partial gastrectomy was performed with an antecolic valved Billroth II type of anastomosis.

POSTOPERATIVE COURSE Recovery was uninterrupted but one month after discharge he was readmitted and appendicectomy performed for typical acute appendicitis. Since then he has remained well for 15 months with no recurrence of ulcer symptoms, eating a full normal diet. $\mathrm{He}$ is no longer obese, and is active at school.

POSTOPERATIVE ACID STUDIES The volume of a 12-hour fasting overnight gastric aspirate was $169 \mathrm{ml}$, containing 3 m-equiv free acid. Augmented histamine stimulation was now within normal limits (Fig. 1). Very similar results were obtained on repeating these tests 15 months later.

PATHOLOGY OF THE TUMOUR The pathology report (Dr G. I. Horsfield) read as follows: 'The specimen consists of a nodular firm white encapsulated tumour measuring $6 \times 4 \times 3 \mathrm{~cm}$ and weighing $30 \mathrm{~g}$ (Fig. 2). Sections show a cellular islet-cell tumour with bands of fibrous tissue separating hyperplastic cellular nests(Fig. 3). The cells are columnar and cuboid with round or oval nuclei showing a fine chromatin network. The cells are arranged in anastomotic trabeculae or ribbon-like structures and areas of rosette formation are present which in parts have a superficial resemblance to a carcinoid tumour although specific stains for carcinoid tissue are negative. Mitotic figures are not present. Masson's trichome and Gomori's chrome haematoxylin phloxin stains show no evidence of alpha or beta granule activity.'

GASTRIN-LIKE ACTIVITY ASSAY The presence in the tumour of a substance with gastrin-like activity was confirmed by Professor R. A. Gregory (1968). The tumour was extracted according to the first stage of the method used by Gregory and Tracy (1964) for the isolation of gastrin from antral mucosa. This method provides a crude but potent and histamine-free extract. The extract was tested by subcutaneous injection into a conscious dog provided with a completely denervated pouch of the body of the stomach. The pouch gave a prompt acid secretory response, establishing the presence in the tumour extract of gastrin-like activity.

\section{DISCUSSION}

Peptic ulcer has been recorded in children for 125 years (Rufz, 1843) but ulceration secondary to a gastrin-secreting adenoma is rare. Guthrie (1942) found only nine cases of peptic ulcer in 6,069 necropsies at Glasgow Children's Hospital, while from case records Proctor (1925) found only three children in 8,260 chronic ulcer cases at the Mayo Clinic. In later studies peptic ulceration in childhood appears to be more frequent. Indeed Proctor estimated that symptoms of 16 of the last 1,000 of his gastric, and 26 of the last 1,000 of his duodenal, cases in adults started in childhood. Ramirez Ramos, Kirsner, and Palmer (1960) of Chicago traced 32 cases of peptic ulcer and Michener, Kennedy, and DuShane (1960) reported 92 cases of duodenal ulcer from the Mayo Clinic, all in children. Goldberg (1957) described 20 cases of duodenal ulcer occurring in patients between the ages of 7 and 15 years from Booth Hall Hospital, near Manchester, in a single five-year period. At Bradford Children's Hospital nine cases of duodenal ulcer and one case of gastric ulcer have been diagnosed during the last 12 years in children of ages 1 month to 13 years. Most children with peptic ulceration respond to medical treatment. In Goldberg's series only two patients required operation (for perforations), and the current case is the first in Bradford.

Usually the failure of what would normally be regarded as adequate surgical treatment first suggests the possibility of the Zollinger-Ellison syndrome, but the condition may be suspected during the initial barium studies. Weber, Lewis, and Heasley (1959) emphasized the 'lacy, cobweblike appearance of the small bowel' with apparent thickening of the valvulae conniventes in three patients, two of them brothers. They stressed that this radiological appearance must have been due to hypermobility, as it was not constant in serial films; nor was it present at operation or at postmortem examination. Dilatation of the proximal duodenum was noted in the early case of Brown, Neville, and Hazard (1950). Both these features were present in another early case, that of Forty and Barrett (1952). Each of the above five patients had had diarrhoea preceding the pain for considerable periods. Amberg, Ellison, Wilson, and Zboralske (1964), reviewing the radiological diagnosis in cases of this syndrome, confirmed the duodenal ileus and the specific abnormality of the jejunal pattern. 


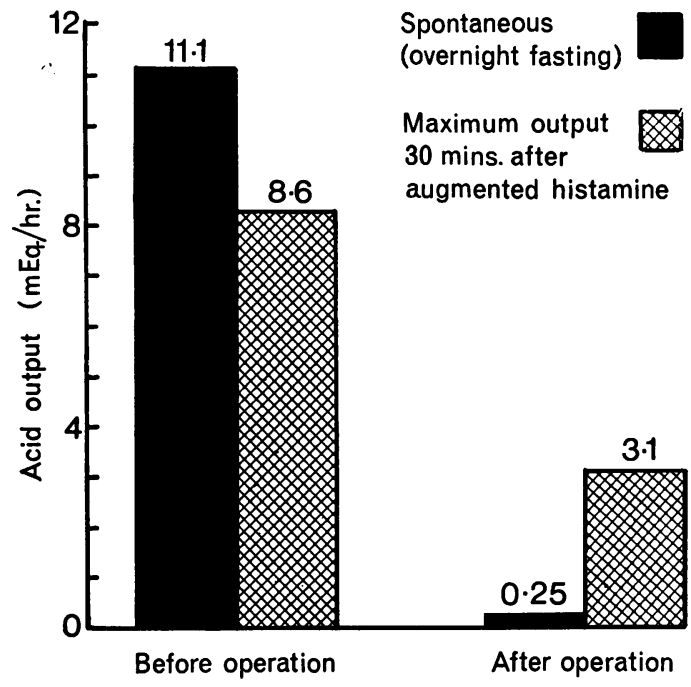

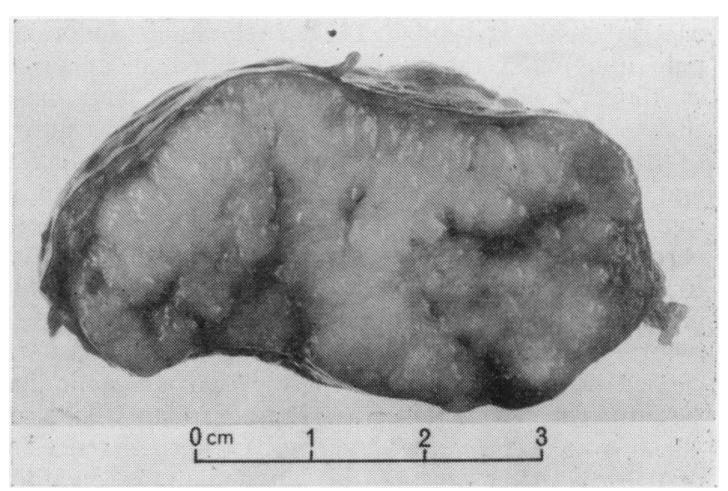

FIG. 2. View of the cut surface of the tumour.

FIG. 1. Preoperative and postoperative acid studies.

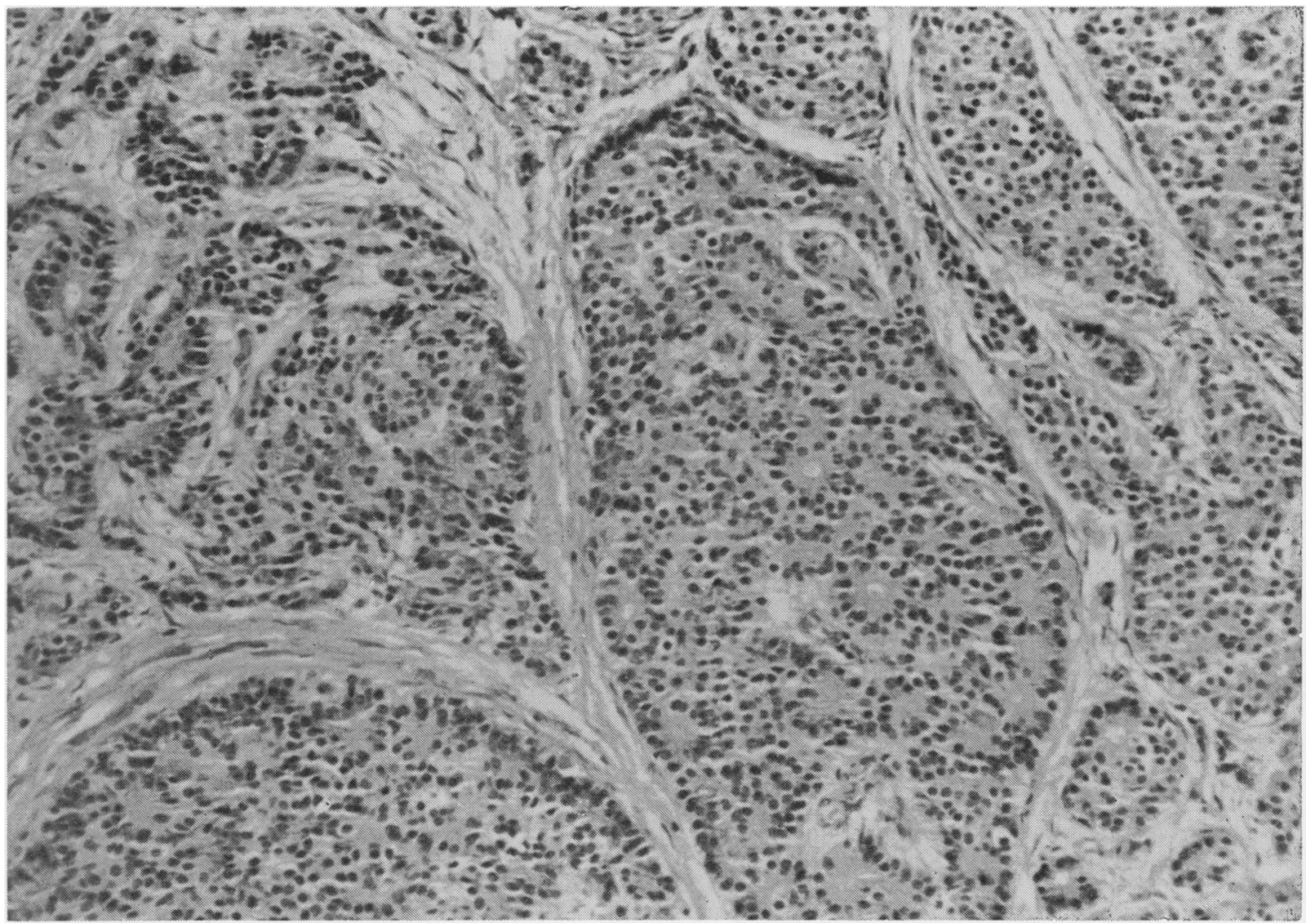

FIG. 3. Low-power photomicrograph of the tumour. Haematoxylin and eosin. 
They also emphasized mucosal hypertrophy and the appearance of large amounts of resting fluid in the unobstructed stomach. Primary jejunal ulcers may be pathognomonic but they are only seen in one quarter of cases, and were absent in this instance.

The diagnosis was confirmed by the preoperative acid studies (Fig. 1), which were very similar to those in the 11-year-old boy described by Wilson and Ellison (1965), whose 12-hour overnight fasting gastric aspirate measured $1,200 \mathrm{ml}$ and contained $117 \mathrm{~m}$-equiv $/ \mathrm{HCl}$.

Because of the surgeon's frequent inability to remove all gastrin-secreting tumour tissue, Wilson and Ellison (1966) recommended initial total gastrectomy. Of the nine children with ulcerogenic islet cell tumours who had gastric resections before their 15th birthdays, five eventually underwent total gastrectomy and remained well with residual tumour tissue; the other four, who had residual tumour tissue and had had partial gastrectomies, died from complications of hypersecretion. Our patient has remained well, acid secretion remaining normal 15 months after excision of the pancreatic tumour and one-third partial gastrectomy.

We would like to thank Dr M. W. Arthurton, Dr P. P. Franklyn, Dr G. I. Horsfield, and Mr F. R. R. Martin, under whose care this patient was managed, and Professor R. A. Gregory, of the University of Liverpool, for his assay of gastrin-like activity of the tumour.

\section{REFERENCES}

Amberg, J. R., Ellison, E. H., Wilson, S. D., and Zboralske, F. F. (1964). Roentgenographic observations in the ZollingerEllison syndrome. J. Amer. med. Ass., 190, 185-187.

Brown, C. H., Neville, W. E., and Hazard, J. B. (1950) Islet-cell adenoma, without hypoglycemia, causing duodenal obstruction. Surgery, 27, 616-620.

Forty, F., and Barrett, G. M. (1952). Peptic ulceration of the third part of the duodenum associated with islet-cell tumours of the pancreas. Brit.J. Surg., 40, 60-63.

Goldberg, H. M. (1957). Duodenal ulcers in children. Brit. med. J., $1,1500-1502$.

Gregory, R. A. (1968). Personal communication.

-, Grossman, M. I., Tracy, H. J., and Bentley, P. H. (1967). Nature of the gastric secretagogue in Zollinger-Ellison tumours. Lancet, 2, 543-544.

- and Tracy, H. J. (1964). The constitution and properties of two gastrins extracted from hog antral mucosa. Gut, 5, 103-117.

-, - French, J. M., and Sircus, W. (1960). Extraction of a gastrin-like substance from a pancreatic tumour in a case of Zollinger-Ellison syndrome. Lancet, 1, 1045-1048.

Guthrie, K. J. (1942). Peptic ulcer in infancy and childhood, with a review of the literature. Arch. Dis. Childh., 17, 82-94.

Jackson, R. H., Blair, E. L., Dawson, P. J., Reed, J. D., and Watts, W. P. T. (1963). Gastrin activity of tumour tissue in a child with the Zollinger-Ellison syndrome. Lancet, 2, 908-912.

Michener, W. M., Kennedy, R. L. J., and DuShane, J. W. (1960). Duodenal ulcer in childhood. Amer. J. Dis. Child., 100, 814-817.

Proctor, O. S. (1925). Chronic peptic ulcer in children. Surg. Gynec. Obstet., 41, 63-69.

Ramirez Ramos, A., Kirsner, J. B., and Palmer, W. L. (1960). Peptic ulcer in children. A.M.A.J. Dis. Child., 99, 135-148.

Rufz, E. (1843). Perforations spontanées des intestins. Gaz. med. Paris, 11, 673-677 (quoted in Proctor, 1925).

Weber, J. M., Lewis, S., and Heasley, K. H. (1959). Observations on the small bowel pattern associated with the ZollingerEllison syndrome. Amer. J. Roentgenol., 82, 973-977.

Wilson, S. D., and Ellison, E. H. (1965). Total gastric resection in children with the Zollinger-Ellison syndrome. Arch. Surg., 91, 165-173.

_- (1966). Survival in patients with the Zollinger-Ellison syndrome treated by total gastrectomy. Amer. J. Surg., 111, 787-791.

Zollinger, R. M., and Ellison, E. H. (1955). Primary peptic ulcerations of the jejunum associated with islet cell tumors of the pancreas. Ann. Surg., 142, 709-728. 